Proceedings of the 2018 International Scientific Conference 'Economic Sciences for Agribusiness and Rural Economy' No 1, Warsaw, 7-8 June 2018, pp. 281-286

\title{
INTELLECTUAL PROPERTY PROTECTION TOOLS IN THE ACTIVITIES OF INNOVATIVE GASTRONOMIC ENTERPRISES OF THE MAZOWIECKIE VOIVODESHIP
}

\author{
Agnieszka Bobola, Eng $\mathrm{PhD}^{1}$; Irena Ozimek, Professor²; \\ Julita Szlachciuk, $\mathrm{PhD}^{3}$; Olena Kulykovets, $\mathrm{MSc}^{4}$ \\ 1, 3, 4 Faculty of Human Nutrition and Consumer Sciences, Warsaw University of Life Sciences - SGGW \\ 2 Faculty of Economic Sciences, Warsaw University of Life Sciences - SGGW
}

\begin{abstract}
The aim of the article is to evaluate the use of intellectual property protection tools to secure innovations in catering companies. The first part of the work presents the analysis of selected scientific publications that characterize innovations and tools for intellectual property protection. The second part of the article presents the results of qualitative research, which was obtained from 50 individual in-depth interviews conducted among representatives of gastronomic companies from Mazovian Voivodeship. The research was conducted between April and July 2017. The analysis of the collected research material indicates that catering companies have the potential to create innovations that could be protected by intellectual property tools. Unfortunately the scale of practical use of this tool is small.
\end{abstract}

Keywords: intellectual property, intellectual property protection tools, innovations, catering company JEL codes: O34, L66, M2

\section{INTRODUCTION}

The market of gastronomic services in Poland is developing dynamically. The estimated value was approximately 36,12 billion PLN in 2017 and increased by more than $10.5 \%$ compared to 2016 year (GfK, 2017).

Market conditions and competitiveness requirements determine enterprises to properly use of intel- lectual capital as unique intangible resources (Nemec Rudez and Mihalic, 2007). In order to obtain competitive advantage companies need to pay attention not only to the material components, but also on those elements that are dependent on the intellectual potential of the individuals.

The customer choice of a particular gastronomic place is determined by many different factors which include quality of dishes, prices and location, service

${ }^{1}$ Corresponding author: Nowoursynowska 159c, building 32,02-776 Warsaw, Poland, agnieszka_bobola@sggw.pl, +4822 5937012

${ }^{2}$ Corresponding author: Nowoursynowska 166, building 6, 02-776 Warsaw, Poland, irena_ozimek@sggw.pl, +4822 5934187

${ }^{3}$ Corresponding author: Nowoursynowska 159c, building 32,02-776 Warsaw, Poland, julita_szlachciuk@sggw.pl, +4822 5937132

${ }^{4}$ Corresponding author: Nowoursynowska 159c, building 32,02-776 Warsaw, Poland, olena_kulykovets@sggw.pl, +4822 5937149 
level, varied menu, interior décor/atmosphere of the premises, promotions or recommendations of other customers (IQS, 2017). In order to meet these different requirements, the owners introduce various innovations, which in most cases may be secured by intellectual property protection tools such as trade secret, industrial property rights or copyright laws/related rights.

The purpose of this article is to assess the use of intellectual property protection tools to secure innovation in catering companies.

Innovations and tools for intellectual property protection from theoretical perspective

The term 'innovation' comes from the Latin words innovatio or innovare, which means 'renew, refresh or change' (Kopaliński, 2006). The literature indicates a number of different approaches and interpretations to characterize the essence of innovation (Montoya-Weiss and Calantone, 1994). For this reason, there is a lack of a definition on this concept (Kuznets, 1959; Schumpeter, 1960; Whitfield, 1979; Freemen and Soete, 1997; Hargadon and Sutton, 2000; Janasz, 2003; Hildreth and Kimble, 2004; Drucker, 2004; Oslo Manual, 2005; Simpson, Siguaw i Enz, 2006).

The wide variation in the definitions relating to innovation led the creation of multiple classifications which have been divided due to the subject of innovations, effects of innovations, originality of changes or the nature of innovations and their importance from the point of view of the changes they cause in company (Sławińska, 2015). The most basic and most frequently used classification is the division of innovations due to the subject of innovation which has a technological and non-technological character. According to this division, technological innovations are connected with product and process and non-technological are related to organizational and marketing innovations. Product innovations are concerning products or services that could be refined in terms of usability and functionality or could be new as well as significantly improved. In turn, process innovations concern the implementation of a new or significantly improved method of production or provision of services. Organizational innovations include the implementation of advanced man- agement techniques, new or significantly changed business strategies, and the introduction of significantly changed organizational structure. Marketing innovations refer to individual elements of the marketing mix concept (Oslo Manual, 2005).

In the context of considerations, it is worth to mention that innovative solutions that are created and used by companies in most cases can be protected on the basis of copyright and related rights (Act of 4 February 1994 on Copyright and Related Rights), industrial property rights (Act of 30 June 2000 on Industrial Property) or regulations on combating unfair competition (Act of 16 April 1993 on Combating Unfair Competition). Especially if the entrepreneur intends to treat such solutions as elements of property within the meaning of the Civil Code (Act of 23 April 1964 Civil Code) and property components in relation to the Accounting Act (Act of 29 September 1994 on Accounting).

According to the Article 55 of the Civil Code, the enterprise is an organized set of tangible and intangible elements intended for conducted business activity, including in particular:

- a designation distinguishing the enterprise or its separated parts;

- the ownership of immovable and movable, including equipment, materials, goods and products, and other real rights to immovable and movable;

- rights under contracts for the tenancy and lease of immovable or movable and rights to use immovable or movable under other legal relationships;

- receivables, rights attached to securities, and cash;

- concessions, licenses and permits;

- patents and other industrial property rights;

- copyright and neighbouring rights;

- secrets of the enterprise;

- books and documents related to the business activity.

This regulation is the basis for effective protection in the event of abuse by third-parties among intangible assets owned by the enterprise. The tools that protect them are listed in the Civil Code, and include industrial property rights, copyrights and related rights, trade secrets. 


\section{MATERIALS AND METHODS}

The conducted study was based on the interview technique that belongs to the diagnostic survey methods. The tool was the author's questionnaire, which contained ten issues related to intellectual property management in the company and six questions related to metrics.

The research was conducted between April and July 2017. The study was extensive and involved 134 business entities operating in food industry. The article presents the partial results of about 50 companies from catering sector operated in the Mazovian Voivodeship (Table 1).

A significant group was entities of sole proprietorship (48\%) and limited liability companies (32\%) em- ploying from 4 to 10 persons (38\%). Assessing own financial situation, in most cases respondents stated that it is good or very good. A representative of only one company assessed the financial situation of his company as unsatisfactory.

\section{RESULTS AND DISCUSSION}

Over $2 / 3$ of surveyed companies' representatives questioned about the tools of intellectual property protection that are used in their gastronomic companies indicated the trademark and the trades secret (Fig. 1).

Respondents declared as the trade secret protection for recipes and procedures as well as databases regarding suppliers and customers. However, atten-

Table 1. Characteristics of surveyed gastronomic companies $(N=50)$

\begin{tabular}{|c|c|c|c|}
\hline Criteria & Variants & Number & $\begin{array}{l}\text { Structure } \\
\quad(\%)\end{array}$ \\
\hline \multirow{6}{*}{$\begin{array}{l}\text { Organizational } \\
\text { and legal form }\end{array}$} & sole proprietorship & 24 & 48 \\
\hline & limited liability company & 16 & 32 \\
\hline & joint-stock company & 5 & 10 \\
\hline & partnership & 2 & 4 \\
\hline & limited partnership & 2 & 4 \\
\hline & general partnership & 1 & 2 \\
\hline \multirow{4}{*}{$\begin{array}{l}\text { Number } \\
\text { of persons } \\
\text { employed in } \\
\text { the company }\end{array}$} & up to 3 persons & 8 & 16 \\
\hline & 4-10 persons & 19 & 38 \\
\hline & $11-50$ persons & 14 & 28 \\
\hline & 51 and more persons & 9 & 18 \\
\hline \multirow{4}{*}{$\begin{array}{l}\text { Subjective } \\
\text { assessment of } \\
\text { the financial } \\
\text { situation of } \\
\text { the company }\end{array}$} & $\begin{array}{l}\text { it's not enough for us to cover the monthly costs associated with the } \\
\text { functioning of the company and we have to pay extra for this business } \\
\text { from our own pocket }\end{array}$ & 1 & 2 \\
\hline & $\begin{array}{l}\text { we have a lot of financial freedom, we achieve satisfactory financial } \\
\text { results from our business }\end{array}$ & 8 & 16 \\
\hline & $\begin{array}{l}\text { we systematically invest in the development of our company, we } \\
\text { regulate current expenses on time }\end{array}$ & 15 & 32 \\
\hline & $\begin{array}{l}\text { it is enough for us to cover current expenses, but we need to save } \\
\text { money for major investments }\end{array}$ & 25 & 50 \\
\hline
\end{tabular}

Source: own study. 


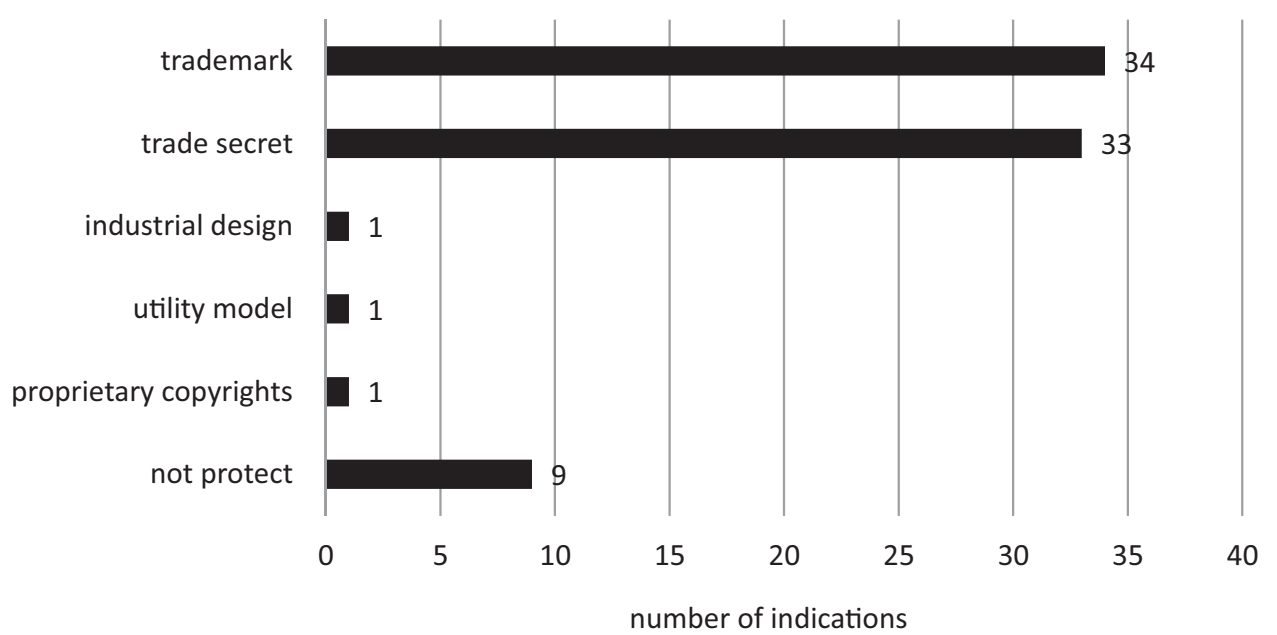

Figure 1. Tools for protection of intellectual property in the surveyed gastronomic companies Source: own study, respondents could indicate more than one answer.

tion should be paid that not all surveyed companies properly implemented security for the declared trade secrets. In 36 enterprises there were no regulations regarding the secrecy of confidentiality. Some of the respondents emphasized that 'employees should not reveal recipes, but we do not have such records in the contract', 'once there was a disclosure of the recipe, so we are planning to create some riles'. A condition that must be met in order for the entity to use benefit from the protection of trade secret is to take the necessary measures to preserve confidentiality enshrined in the Act on Combating Unfair Competition. Only 14 surveyed enterprises had implemented regulations regarding intellectual property.

The respondents were asked about whom responsible is for intellectual property management in the company indicated the owners of enterprises, presidents, board members, place managers, the marketing department, and the kitchen chef or in individual cases people specially employed for this purpose. In two of the surveyed enterprises such activities were commissioned by a law company.

In thirty-two entities, no activities related to the development of intellectual property are foreseen in the near future. The trademark intends to submit 8 entrepreneurs, 10 companies declared willingness to benefit from training on how to protect and manage intellectual property and the possibility of obtaining EU funding for the protection of industrial property.
About 11 companies also indicated the willingness to use the services of consulting firms in the scope of the possibility of obtaining protection for intellectual property. A representative of one company pointed to the desire to purchase a license for industrial property rights and one of the respondents enigmatically answered that 'perhaps yes'.

This situation was undoubtedly influenced by barriers identified by 48 respondents regarding the possibility of using intellectual property tools to protect innovative solutions. These include, among others:

- low level of knowledge - 33,

- not enough training, information and advice (especially unpaid) - training -24 , information -22 , consulting -13 ,

- underestimation of intellectual property in company -20 ,

- difficulties in dealing with offices granting industrial property rights -16 ,

- lack of strategy regulating the intellectual property area in the enterprise -15 ,

- small internal promotion of intellectual property -13 ,

- lack of employee involvement - 10,

- misappropriation of intellectual property - 9 ,

- lack of funds and high costs of obtaining protection -4 ,

- difficulties in monitoring and enforcing fraud -4 . 
The confrontation of barriers identified by respondents with the results of a study carried out in 2009 and 2010 by the Polish Chamber of Commerce (KIG, n.d.) on a group of 720 companies showing barriers related to intellectual property management shows that despite the passage of time, the most important limitations are still a small number of trainings (55\% indications in the KIG study, 24 indications in the own study) and consultancy (37\% indications in the KIG study, 13 indications in the own study), low level of knowledge (43\% - sufficient knowledge of employees about intellectual property management and $37 \%$ - insufficient knowledge of the management on the subject of intellectual property management in the indications of KIG study, 33 indications in the own study) and lack of importance to intellectual property in the enterprise (33\% indications in the KIG study, 20 indications in the own study).

\section{CONCLUSIONS}

Intellectual property plays an increasingly important role in the modern world. All innovations implemented into enterprises are the result of the work of human mind and obtained results should be protected.

On the basis of the results it can be concluded:

1. The most frequently used tools to protect intellectual property in catering enterprises were trademarks and trade secrets.

2. Most of the surveyed enterprises do not sufficiently secure their intellectual property (e.g. lack of regulations).

3. The biggest barriers hindering the use of intellectual property protection tools according to the respondents were: low level of knowledge, lack of training and consultancy (especially free of charge) and the lack of importance to protect intellectual property of enterprise. This state of affairs probably was, for most of the surveyed companies, reflected in the lack of interest in the development of this area.

\section{REFERENCES}

1. Drucker, P.F. (2004). Innowacja i przedsiębiorczość [Innovation and entrepreneurship]. EMKA, Warszawa.
2. Freemen, Ch., Soete, L. (1997). The Economics of Industrial Innovation. Pinter, London.

3. Hargadon, A., Sutton, R.I. (2000). Building an Innovation Factory. Harvard Business Review, 78 (3), pp. 157-166.

4. Hildreth, P., Kimble Ch. (2004). Knowledge Networks. Innovation Through Communities of Practice. Idea Group Publishing, USA.

5. GfK (2017). Dobre prognozy dla polskiego rynku HoReCa [Good forecasts for the Polish market of HoReCa]. Retrieved from: https://www.gfk.com/ pl/aktualnosci/press-release/dobre-prognozy-dlapolskiego-rynku-horeca/ [Accessed 30.05.2018].

6. Janasz, W. (2003). Innowacje i ich miejsce w działalności przedsiębiorstw [Innovation and their place in business operations]. In: Janasz, W. (ed.) Innowacje w modelach działalności przedsiębiorstw [Innovations in business models of enterprises]. Wydawnictwo Uniwersytetu Szczecińskiego, Szczecin, p. 63.

7. KIG (n.d.). Zarządzanie własnością intelektualną [Intellectual property management]. Retrieved from: http://www.zwi.kig.pl/pliki/ZWI_fakty_i_liczby.pdf [Accessed 30.05.2018].

8. Kopaliński, W. (2006). Słownik wyrazów obcych i zwrotów obcojęzycznych, innowacja [Dictionary of foreign words and foreign-language phrases]. Wydawnictwo Naukowe PWN, Warszawa.

9. Kuznets, S. (1959). Six Lectures on Economic Growth. Free Press of Glencoe, Glencoe.

10. Montoya-Weiss, M.M., Calantone, R. (1994). Determinants of new product performance. A review and metaanalysis. Journal of Product Innovation Management, 11, pp. 397-417.

11. Nemec Rudez, H., Mihalic, T. (2007). Intellectual capital in the hotel industry. A case from Slovenia. Hospitality Management, 26 (1), pp. 188-199.

12. Oslo Manual (2005). Proposed Guidelines For Collecting And Interpreting Technological Innovation Data, http://www.oecd.org/sti/inno/2367580.pdf [Accessed 31.04.2018].

13. IQS (2017). Polska na talerzu [Poland on the plate]. Retrieved from: http://www.mediamakro.pl/file/attachment/1170956/44/polska_na_talerzu_2017.pdf [Accessed 30.05.2018].

14. Schumpeter, J.A. (1960). Teoria rozwoju gospodarczego [Theory of economic development]. PWN, Warszawa.

15. Sławińska, M. (2015). Innowacje marketingowe w działalności przedsiębiorstw handlowych [Marketing Innovations in the Operation of Commercial Enterpri- 
ses]. Annales Universitatis Mariae Curie-Skłodowska, Sectio H. Oeconomia, 49, pp. 157-167.

16. Simpson, P.M., Siguaw, J.A., Enz, C.A. (2006). Innovation orientation outcomes. The good and the Bad. Journal of Business Research, 59 (10-11), pp. 1133-1141.

17. Ustawa z dnia 16 kwietnia 1993 r. o zwalczaniu nieuczciwej konkurencji [Act of 16 April 1993 on Combating Unfair Competition]. Journal of Laws 2018, item 419.

18. Ustawa $\mathrm{z}$ dnia 23 kwietnia 1964 r. Kodeks cywilny [Act of 23 April 1964 Civil Code]. Journal of Laws 2018, item 459.
19. Ustawa z dnia 29 września 1994 r. o rachunkowości [Act of 29 September 1994 on Accounting]. Journal of Laws 2018, item 395.

20. Ustawa z dnia 4 lutego 1994 r. o prawie autorskim i prawach pokrewnych [Act of 4 February 1994 on Copyright and Related Rights]. Journal of Laws 2017, item 880.

21. Ustawa z dnia 5 kwietnia 2017 r. Prawo własności przemysłowej [Act of 30 June 2000 Industrial Property]. Journal of Laws 2017, item 776.

22. Whitfield, P.R. (1979). Innowacje w przemyśle [Innovations in industry]. PWE, Warszawa. 